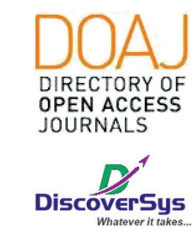

Published by DiscoverSys

\section{Infeksi Saluran Kemih Sebagai Faktor Risiko Terjadinya Persalinan Preterm}

\author{
Sugianto, ${ }^{1 *}$ I Wayan Megadhana, ${ }^{2}$ Ketut Suwiyoga, ${ }^{2}$ \\ Tjokorda Gde Agung Suwardewa, ${ }^{2}$ I Gusti Putu Mayun Mayura, ${ }^{2}$ \\ Anom Suardika, ${ }^{2}$ I Wayan Artana Putra ${ }^{2}$
}

\title{
ABSTRACT
}

Introduction: Preterm labor is one of the major problem and challenge in the obstetric field, since it is associated with high mortality and morbidity in newborn. Preterm delivery around $39.6 \%$ was thought to be caused by infection. One of the most common causes of preterm labor is Urinary Tract Infection (UTI). This study aims to determine the role of UTI in pregnancy as a risk factor for preterm labor.

Method: This study is a case control study conducted from February 2019 to November 2019. This study involved 52 women (26 case group and 26 control group) with gestational ages over 20 weeks and under 37 weeks, where in case group with signs and symptoms of threatened of preterm delivery and in control group with no signs and symptoms of threatened of preterm delivery. The research sample is maternal peripheral blood for evaluation of Haemoglobin and mid stream urine for evaluation of Bacteriuria and Urine Culture - Resistance Test.

Result: In this study, there were no differences in the value of characteristics of maternal age, gestasional age, and gravidity between the two groups ( $p>0.05$ ). Pregnancy with UTI (asymptomatic bacteriuria) increased the risk of preterm labor by 13 times compared to pregnancies without UTI $(O R=13.24 ; 95 \% \mathrm{Cl}=1.53-114.30 ; \mathrm{p}=0.005)$. Conclusion: Based on the results of this study it can be concluded that a pregnancy with a UTI has a 13 times higher risk of experiencing preterm labor when compared to a pregnancy without a UTI.
1PPDS-1 Obstetri dan Ginekologi, Fakultas Kedokteran, Universitas Udayana-RSUP Sanglah Denpasar, Bali-Indonesia

${ }^{2}$ Departemen/KSM Obstetri dan Ginekologi, Fakultas Kedokteran, Universitas Udayana-RSUP Sanglah Denpasar, Bali-Indonesia

*Correspondence to: Sugianto, PPDS-1 Obstetri dan Ginekologi, Fakultas Kedokteran, Universitas Udayana-RSUP Sanglah Denpasar, Bali-Indonesia sugianto.dr@gmail.com

Diterima: $30-06-2020$

Disetujui: $12-07-2020$

Diterbitkan: 01-08-2020
Keywords: Preterm labor, urinary tract infection, pregnancy.

Cite This Article: Sugianto, Megadhana, I.W., Suwiyoga, K., Suwardewa, T.G.A., Mayura, I.G.P.M., Suardika, A., Putra, I.W.A. 2020. Infeksi Saluran Kemih Sebagai Faktor Risiko Terjadinya Persalinan Preterm. Intisari Sains Medis 11(2): 823-829. D0I: 10.15562/ism.v11i2.774
Pendahuluan: Persalinan preterm adalah salah satu masalah dan tantangan dalam bidang obstetrik, terkait dengan tingginya mortalitas dan morbiditas pada bayi yang dilahirkan. Persalinan preterm sekitar 39,6\% disebabkan oleh infeksi. Salah satu penyebab yang paling umum adalah Infeksi Saluran Kemih (ISK). Penelitian ini bertujuan untuk mengetahui peranan ISK dalam kehamilan sebagai faktor risiko terjadinya persalinan preterm.

Metode: Penelitian ini adalah studi kasus kontrol yang dilakukan dari Februari 2019 hingga November 2019. Penelitian ini melibatkan 52 wanita (26 kelompok kasus dan 26 kelompok kontrol) dengan usia kehamilan lebih dari 20 minggu dan di bawah 37 minggu, di mana dalam kelompok kasus dengan adanya tanda dan gejala ancaman persalinan preterm dan dalam kelompok kontrol tanpa adanya tanda dan gejala ancaman persalinan preterm. Sampel penelitian adalah darah tepi ibu untuk keperluan menilai kadar Hemoglobin dan urin aliran tengah untuk keperluan evaluasi adanya Bakteriuria dan selanjutnya untuk Kultur Urin - Uji Resistensi.

Hasil: Dalam penelitian ini, diketahui bahwa tidak ada perbedaan bermakna dalam karakteristik usia ibu, usia kehamilan, dan graviditas antara kedua kelompok $(p>0,05)$. Diketahui bahwa kehamilan dengan ISK (bakteriuria asimptomatik) meningkatkan risiko persalinan preterm sebesar 13 kali dibandingkan dengan kehamilan tanpa ISK $(0 R=13,24 ; \mathrm{IK} 95 \%=1,53-114,30 ; p=0,005)$.

Simpulan: Berdasarkan hasil penelitian ini disimpulkan bahwa kehamilan dengan ISK memiliki risiko 13 kali lebih tinggi mengalami persalinan preterm bila dibandingkan dengan kehamilan tanpa ISK.

Kata kunci: Persalinan preterm, infeksi saluran kencing, kehamilan.

Cite Pasal Ini: Sugianto, Megadhana, I.W., Suwiyoga, K., Suwardewa, T.G.A., Mayura, I.G.P.M., Suardika, A., Putra, I.W.A. 2020. Infeksi Saluran Kemih Sebagai Faktor Risiko Terjadinya Persalinan Preterm. Intisari Sains Medis 11(2): 823-829. D0I: 10.15562/ism.v11i2.774

\section{PENDAHULUAN}

Sampai saat ini persalinan preterm masih merupakan masalah dan tantangan yang serius dalam bidang obstetrik, terkait dengan tingginya mortalitas dan morbiditas pada bayi yang dilahirkan. Perkembangan ilmu pengetahuan dan teknologi yang ada saat ini belum dapat secara maksimal menurunkan angka kejadian persalinan preterm, dimana penyebab, mekanisme dan patofisiologis yang berkaitan dengan terjadinya hal tersebut melibatkan banyak faktor yang belum dapat 
digambarkan secara jelas. Persalinan preterm akan selalu diawali dengan adanya tanda dan gejala ancaman persalinan preterm berupa timbulnya kontraksi dan perubahan pada serviks, bila tanda dan gejala tersebut berhasil dikenali dan ditangani maka ancaman tersebut tidak akan berlanjut sebagai suatu persalinan preterm. Sehingga upaya mengenali adanya suatu ancaman persalinan preterm dan upaya pencegahannya menjadi hal yang sangat penting. Salah satu penyebab persalinan preterm adalah adanya infeksi, dan infeksi yang sering terjadi pada wanita hamil adalah Infeksi Saluran Kemih (ISK), sehingga ISK sering dikaitkan dengan timbulnya persalinan preterm.

Di Amerika Serikat angka kejadian persalinan preterm dalam setahun sebesar $12,5 \%$, sementara di Eropa bervariasi antara 5\% sampai 7\% dari seluruh total persalinan. Prematuritas masih berperan sebagai penyumbang terbesar kematian bayi baru lahir di beberapa negara berkembang, dimana pada salah satu studi didapatkan data angka kejadian mortalitas pada bayi preterm sebesar $75-80 \%$, dan sekitar $40 \%$ dari kematian tersebut terjadi pada usia kehamilan $<32$ minggu. ${ }^{1}$ Prematuritas adalah sebagai penyumbang terbesar penyebab kematian neonatal dan kematian pada anak di bawah usia 5 tahun. $^{2}$

Persalinan preterm menjadi perhatian karena bayi yang lahir terlalu dini mungkin belum sepenuhnya berkembang sempurna dan mungkin terlahir dengan membawa permasalahan kesehatan yang serius. ${ }^{3}$ Bayi yang lahir preterm rentan terhadap penyakit serius atau kematianselama periode neonatal. ${ }^{2}$ Upaya global untukmengurangi angka kematian anak menuntut dilakukannya tindakan mendesak untuk mengenali dan mencegah terjadinya persalinan dan kelahiran preterm dikarenakan kematian dan morbiditas bayi setelah kelahiran preterm dapat dikurangi melalui intervensi yang diberikan ke ibu sebelum atau selama kehamilan, dan untuk bayi preterm setelah ahir. ${ }^{2}$

Banyak faktor yang disebut sebagai faktor risiko terjadinya persalinan preterm, antara lain infeksi, inflamasi, perdarahan, regangan dinding uterus yang berlebih (misalnya kehamilan multipel, polihydramnion), trauma, stress, proses imunologis dan inkompetensi serviks. ${ }^{1}$ Meskipun demikian, mekanisme terjadinya persalinan preterm sampai saat ini masih belum sepenuhnya dapat dipahami. ${ }^{4}$

Dari berbagai faktor yang mungkin menjadi penyebab dan memicu terjadinya persalinan preterm, infeksi adalah satu-satunya proses patologis yang hubungan kausalnya dengan terjadinya persalinan preterm telah dapat digambarkan dan patofisiologi molekular yang terlibat di dalamnya telah dapat dijelaskan. ${ }^{4}$ Sekitar 39,6\% dari persalinan preterm diduga disebabkan oleh karena infeksi.
Salah satu infeksi yang cukup banyak terjadi pada kehamilan adalah ISK. ${ }^{1}$ ISK yang tidak diobati dapat dikaitkan dengan komplikasi obstetrik yang serius. ${ }^{5}$ ISK telah dilaporkan terjadi pada $20 \%$ dari wanita hamil dan merupakan penyebab paling sering wanita hamil dirawat di bangsal obstetri. ${ }^{5}$ Biaya perawatan ISK setiap tahunnya diperkirakan sekitar \$1,6 miliar dolar dan terus mengalami peningkatan. ${ }^{6}$

Sebagian besar kasus ISK disebabkan oleh Enterobacteriaceae, terutama Escherichia coli, Klebsiella dan spesies Enterobacter. Organisme ini terhitung sekitar 90\% dari semua ISK yang ditemui selama kehamilan. ${ }^{7,8}$ Pada wanita kehamilan itu sendiri adalah keadaan yang unik dimana terjadi perubahan anatomi dan fisiologis saluran kemih. ${ }^{9}$ Perubahan fisiologis dan anatomis pada kehamilan menyebabkan terjadinya stasis urin, refluks vesikoureterik sekunder, sehingga menyebabkan peningkatan risiko terjadinya ISK. ${ }^{10}$

ISK yang tejadi pada saluran kemih bawah (bakteriuria asimtomatik dan sistitis akut atau yang dikenal dengan istilah infeksi kandung kemih) sementara ISK pada saluran kemih atas (pielonefritis akut atau yang dikenal dengan istilah infeksi ginjal). ${ }^{3}$ Hubungan antara ISK dan pengaruhnya pada kehamilan yang merugikan, pertama kali disampaikan oleh Kass pada tahun 1959 yang menunjukkan data bahwa pengobatan ibu hamil dengan bakteriuria dapat mencegah pielonefritis dan dapat menurunkan angka kejadian persalinan preterm hingga $20 \% .{ }^{11}$ Dari studi yang dilakukan Masteryanto dkk. ${ }^{1}$ didapatkan hubungan yang signifikan antara adanya bakteriuria dengan terjadinya ancaman persalinan preterm. Bakteriuria asimtomatik adalah ISK yang umum terjadi pada wanita dan sekitar 4-7\% terjadi pada kehamilan. ${ }^{12}$ Dari sebuah studi didapatkan data bahwa pada bakteriuria asimptomatik yang tidak diobati sebanyak 20\%-30\% akan berkembang menjadi pielonefritis, sementara disisi lain bila bakteriuria asimtomatik pada kehamilan mendapat pengobatan yang tepat maka akan dapat menurunkan angka kejadian pielonefritis sebesar $80 \%$ sampai $90 \%{ }^{13}$ Penapisan dan pengobatan bakteriuria yang tepat pada populasi ini direkomendasikan untuk mencegah pielonefritis dan masalah perinatal yang merugikan seperti persalinan preterm, prematuritas dan/atau berat badan lahir rendah. ${ }^{10}$ Penapisan untuk ISK telah menjadi standar perawatan kebidanan, dan sebagian besarPedoman perawatan antenatal saat ini mencakup skrining rutin untuk bakteriuria asimtomatik. Penapisan tersebut disarankan oleh The United States Preventive Services Task ForceInfectious Diseases Society of America, The National Institute for Clinical Excellence, The European Association of Urology, The Canadian 
Task Force on Preventive Care, dan juga The Scottish Intercollegiate Guidelines Network. ${ }^{11}$

Berdasarkan data yang telah diuraikan di atas, penelitian ini dimaksudkan untuk mengetahui risiko terjadinya persalinan preterm pada kehamilan dengan ISK. Selanjutnya dapat dijadikan dasar pendekatan terapi antibiotika pada kasus adanya ancaman persalinan preterm berdasarkan pola kuman dan hasil kultur yang ditemukan dalam upaya menurunkan angka kejadian persalinan preterm.

\section{METODE}

Penelitian ini menggunakan rancangan kasus kontrol yang dilakukan di Rumah Sakit Umum Pusat Sanglah Denpasar dan Rumah Sakit Jaringan Pendidikan, serta Bidan Praktek Mandiri yang dilaksanakan mulai bulan Februari 2019 hingga tercapai jumlah sampel yang diinginkan. Populasi dalam penelitian ini adalah ibu hamil dengan usia kehamilan diatas 20 minggu dan dibawah 37 minggu. Sampel penelitian ini diambil dengan cara metode konsekutif. Kriteria inklusi dalam penelitian ini adalah ibu hamil dengan usia kehamilan 20-37 minggu dengan atau tanpa keluhan ISK dan bersedia untuk ikut serta dalam penelitian setelah mendapatkan informed consent. Kriteria eksklusi dalam penelitian ini adalah hipertensi dalam kehamilan dan anemia berat. Pemeriksaan laboratorium yang dikaji dalam penelitian ini yaitu pemeriksaan darah lengkap, urin lengkap yang dilakukan di Instalasi Patologi Klinik RSUP Sanglah, Instalasi Patologi Klinik Rumah Sakit Jaringan Pendidikan Sanglah dan Laboratorium klinik Prodia. Kemudian kultur urin yang dilakukan di Instalasi Mikrobiologi Klinik RSUP Sanglah Denpasar, dan laboratorium klinik Prodia.

Analisis data dalam penelitian ini menggunakan bantuan SPSS versi 21.0. Uji t-independen digunakan untuk membandingkan karakteristik antara variabel numerik, analisis risiko menggunakan perhitungan rasio odds dan uji chi-square. Seluruh nilai dianggap bermakna apabila $\mathrm{p}<0,05$.

\section{HASIL PENELITIAN}

Penelitian ini melibatkan wanita dengan usia kehamilan di atas 20 minggu dan dibawah 37 minggu, dimana sebanyak 26 sampel merupakan kasus dengan ancaman persalinan preterm (kelompok kasus) yang diperoleh dari RSUP Sanglah dan rumah sakit jaringan pendidikan dan 26 sampel lainnya merupakan kehamilan yang tidak disertai dengan ancaman persalinan preterm (kelompok kontrol) yang diperoleh dari bidan praktek mandiri. Penelitian ini melibatkan Instalasi Patologi Klinik RSUP Sanglah, Instalasi Patologi Klinik Rumah Sakit Jaringan Pendidikan Sanglah serta Laboratorium Klinik Prodia sebagai laboratorium pemeriksaan darah lengkap dan urin lengkap, serta juga melibatkan Instalasi Mikrobiologi Klinik RSUP Sanglah dan Laboratorium Klinik Prodia sebagai laboratorium pemeriksaan kultur urin. Pada penelitian ini dari kelompok kasus sebanyak 26 sampel didapatkan 9 kasus ISK, sedangkan dari kelompok kontrol sebanyak 26 sampel didapatkan 1 kasus ISK, dimana total 10 kasus ISK yang ada semuanya merupakan ISK asimtomatik (Bakteriuria asimtomatik). Hasil penelitian selanjutnya disajikan secara lengkap sebagai berikut.

\section{Distribusi Karakteristik Umur, Usia Kehamilan, dan Graviditas pada Kedua Kelompok}

Seperti terlihat pada tabel 1, diketahui bahwa umur, usia kehamilan, dan graviditas didapatkan nilai $\mathrm{p}$ untuk masing-masing adalah $>0,05$, yang menyatakan bahwa tidak adanya perbedaan secara bermakna antara kedua kelompok.

\section{Hasil Pemeriksaan Urin Lengkap dan Kultur Urin pada Kedua Kelompok}

Hasil analisis munujukkan bahwa terdapat perbedaan yang bermakna antara hasil bakteriuria, hasil kultur urin, dan ada tidaknya bakteriuria asimptomatik antara kelompok kasus dengan kelompok kontrol $(\mathrm{p}<0,05)$. Dimana pada kelompok kasus didapatkan ada 9 kasus ISK yang dikategorikan sebagai bakteriuria asimptomatik dan hanya 1 kasus ISK yang dikategorikan sebagai bakteriuria asimptomatik pada kelompok kontrol (Tabel 2).

\section{Risiko terjadinya persalinan preterm pada ISK}

Didapatkan nilai odd ratio (OR) yang menyatakan perbandingan antara risiko persalinan preterm pada keadaan ada tidaknya ISK. Hasilnya terlihat pada

Tabel 1 Karateristik sampel penelitian

\begin{tabular}{lccccccr}
\hline & \multicolumn{2}{c}{ Kelompok Kasus $(\mathbf{n = 2 6})$} & & \multicolumn{2}{c}{ Kelompok Kontrol $(\mathbf{n = 2 6 )}$} & \\
\cline { 2 - 3 } Karakteristik & Rerata & SD & & Rerata & SD & p \\
\hline Umur (tahun) & 26,65 & 7,244 & & 28,04 & 5,575 & 0,444 \\
Usia Kehamilan (mg) & 31,15 & 3,574 & & 29,19 & 3,805 & 0,061 \\
Graviditas & 2,12 & 1,306 & & 2,04 & 1,038 & 0,815 \\
\hline
\end{tabular}


Tabel 2 Hasil pemeriksaan urin lengkap dan kultur urin pada kedua kelompok

\begin{tabular}{llccc}
\hline & & \multicolumn{2}{c}{ Kelompok } & \\
\cline { 3 - 4 } & & Kasus & Kontrol & p \\
\hline \multirow{2}{*}{ Bakteriuria } & Positif & 21 & 26 & \multirow{2}{*}{$0,019^{*}$} \\
& Negatif & 5 & 0 & \\
Hasil Kultur & Tidak Tumbuh & 11 & 23 & \\
& Tumbuh $10^{2}-10^{4}$ & 1 & 2 & $0,005^{*}$ \\
& Tumbuh $10^{5}$ & 9 & 1 & \\
Bakteriuria Asimptomatik & Positif & 9 & 1 & \multirow{2}{*}{$0,001^{*}$} \\
& Negatif & 12 & 25 & \\
\hline
\end{tabular}

${ }^{\star}$ Signifikan $(\mathrm{p}<0,05)$

Tabel 3 Risiko Terjadinya Persalinan Preterm pada ISK

\begin{tabular}{|c|c|c|c|c|c|c|}
\hline & & \multicolumn{2}{|c|}{ Kelompok } & \multirow[b]{2}{*}{ OR } & \multirow[b]{2}{*}{ IK 95\% } & \multirow[b]{2}{*}{$\mathbf{p}$} \\
\hline & & Kasus & Kontrol & & & \\
\hline \multirow[t]{2}{*}{ ISK } & Positif & 9 & 1 & 13,24 & $1,53-114,30$ & $0,005^{\star}$ \\
\hline & Negatif & 17 & 25 & & & \\
\hline
\end{tabular}

${ }^{\star}$ Signifikan $(\mathrm{p}<0,05)$

Tabel 4 Hasil Kultur Bakteri Yang Tumbuh

\begin{tabular}{llcc}
\hline Gram & Bakteri yang tumbuh di kultur & isolat (n) & Persentase (\%) \\
\hline \multirow{2}{*}{ Gram Negatif } & Eschericia coli & 3 & 5.8 \\
& Klebsiella pneumoniae & 2 & 3.8 \\
& Burkholderia cepacia & 2 & 3.8 \\
& Acinetobacter baumannii & 1 & 1.9 \\
\multirow{3}{*}{ Gram Positif } & Enterococcus faecalis & 3 & 5.8 \\
& Staphylococcus aureus & 1 & 1.9 \\
\multirow{2}{*}{ Total } & Staphylococcus haemolyticus & 1 & 1.9 \\
\hline
\end{tabular}

tabel 3 di atas yang menunjukkan bahwa kehamilan dengan ISK merupakan faktor yang meningkatkan risiko terjadinya persalinan preterm sebesar $13 \mathrm{kali}$ dibandingkan dengan kehamilan tanpa ISK. Hasil tersebut juga bermakna secara statistik $(\mathrm{OR}=13,24$; IK 95\% =1,53-114,30; $\mathrm{p}=0,005)$.

\section{PEMBAHASAN}

\section{Distribusi karakteristik umur, usia kehamilan, dan graviditas pada kedua kelompok}

Penelitian yang dilakukan oleh Gebreslasie dkk. ${ }^{14}$ menyimpulkan bahwa, usia pasien dengan kelahiran preterm didominasi oleh kelompok umur 20-34 tahun $(81,6 \%)$ sedangkan dominasi paritas adalah kelompok primigravida sebesar $50,9 \%$. Hal ini sesuai dengan hasil studi yang dilakukan ditempat lain dimana rerata usia masuk ke dalam rentang 20-34 tahun dan rerata paritas mendekati
1 (satu). Studi lainnya juga menunjukkan hasil yang sama dimana usia yang mendominasi adalah usia 21-30 tahun, dan didapatkan data bahwa baik usia maupun paritas tidak mempengaruhi kejadian kelahiran preterm yang signifikan secara statistik. ${ }^{16}$

\section{Hubungan antara hasil pemeriksaan laboratorium dan kultur urin dengan ISK}

Hasil laboratorium menunjukkan bahwa 21 sampel $(80,77 \%)$ pada kelompok kasus terdapat bakteriuria sementara pada kelompok kontrol terdapat sebanyak 26 sampel (100\%) yang terdapat bakteriuria. Sampel yang terdapat bakteriuria kemudian dilakukan kultur urin. Adanya bakteriuria pada kelompok sampel dan kelompok kontrol dapat merupakan petunjuk adanya bakteri penyebab ISK atau mungkin hanya merupakan bakteri yang mengkontaminasi saat pengambilan sampel. Bakteri biasanya berada di pangkal uretra yang berbatasan langsung dengan vagina. Sehingga semua sampel urin yang dikumpulkan kemungkinan bisa mengandung bakteri. ${ }^{16}$

Berdasarkan hasil kultur urin didapatkan bahwa pada kelompok kasus, tidak ditemukan adanya pertumbuhan bakteri sebanyak 11 sampel $(52,4 \%)$, tumbuh $10^{2}-10^{4} \mathrm{CFU} / \mathrm{ml}$ sebanyak 1 sampel $(4,8 \%)$, dan tumbuh $10^{5} \mathrm{CFU} / \mathrm{ml}$ sebanyak 9 sampel $(42,8 \%)$. Sedangkan pada kelompok kontrol, tidak ditemukan adanya pertumbuhan bakteri sebanyak 23 sampel $(88,5 \%)$, tumbuh $10^{2}-10^{4} \mathrm{CFU} / \mathrm{ml}$ sebanyak 2 sampel (7,7\%), dan tumbuh $10^{5} \mathrm{CFU} /$ ml sebanyak 1 sampel $(3,8 \%)$. Karena pada kedua kelompok baik kasus maupun kontrol sampel tidak memiliki gejala atau keluhan terkait ISK maka disimpulkan bahwa didapatkan 10 sampel dengan ISK berupa bakteriuria asimtomatik yang tersebar pada kelompok kasus sebanyak 9 sampel $(42,8 \%)$ dan pada kelompok kontrol sebanyak 1 sampel $(3,8 \%)$. Hasil analisis munujukkan bahwa terdapat perbedaan yang bermakna antara hasil bakteriuria, hasil kultur urin, dan ada tidaknya bakteriuria asimtomatik antara kelompok kasus dengan kelompok kontrol $(\mathrm{p}<0,05)$. Pada penelitian ini diketahui bahwa kejadian bakteriuria asimtomatik adalah sebesar 10 kasus dari 52 sampel penelitian (19.2\%), dimana hasil tersebut lebih rendah dari hasil penelitian yang dilakukan Zahroh dkk. ${ }^{17}$ yang dilakukan pada ibu hamil di Puskesmas Janti Kota Malang (30,2\%), serta penelitian yang dilakukan Riftahani, S (2016) yang dilakukan pada ibu hamil di Kecamatan Gandus Palembang (29,5\%). Pada penelitian itu bakteriuria asimtomatik memiliki hubungan signifikan dengan kejadian ancaman persalinan preterm dengan nilai $\mathrm{p}=0,001(\mathrm{p}<0,05)$, hasil tersebut sesuai dengan studi yang dilakukan Sheiner dkk. ${ }^{18}$ yang menyebutkan bahwa 
bakteriuria asimtomatik merupakan faktor risiko independen yang signifikan terhadap terjadinya ancaman persalinan pretem dengan nilai $\mathrm{p}=0,030$ $(\mathrm{p}<0,05)$.

Dari hasil kultur urin yang tumbuh pada $25 \%$ sampel (13 kasus) seperti yang terlihat pada tabel 4 , didapatkan data bahwa kuman yang tumbuh didominasi oleh kuman gram negatif Eschericia coli sebanyak 3 kasus (5.8\%) dan kuman gram positif Entercoccus faecalis sebanyak 3 kasus (5.8\%). Hasil tersebut sesuai dengan hasil studi yang dilakukan Khan dkk. ${ }^{19}$ terhadap 317 sampel dengan bakteriuria signifikan yang didapatkan dari hasil kultur menunjukkan bahwa bakteri gram negatif terbanyak adalah Eschericia coli yang didapatkan pada 195 sampel (61.51\%) sedangkan untuk bakteri gram positif terbanyak adalah Entercoccus faecalis sebanyak 17 sampel (5.36\%).

\section{Bakteri-bakteri yang tumbuh pada kultur urin}

Selama kehamilan adanya bakteriuria asimtomatik harus mendapat pengobatan untuk mengurangi risiko pielonefritis dan persalinan preterm. Antibiotika Nitrofurantoin, $\beta$-lactam, termasuk golongan Penicilin dan Cephalosporin serta Fosfomycin trometamol termasuk aman digunakan selama kehamilan. ${ }^{20}$ Hasil uji sensitifitas antibiotika menunjukan bahwa bakteri gram negatif 100\% sensitif terhadap antibiotika golongan Carbapenem (Meropenem). Eschericia Coli sensitif terhadap antiobiotika golongan Penicilin yaitu Ampicilin (67\%), Ampicilin sulbactam (67\%) Piperaciline tazobactam (100\%), golongan Cephalosporin generasi ke-1 yaitu Cefazoline (100\%), Cephalosporin generasi ke-3 yaitu Ceftriaxone (67\%), Ceftazidime (67\%), Cefepime (67\%), golongan Carbapenem yaitu Meropenem (100\%), Ertapenem (100\%), golongan Monobactam yaitu Aztreonam (67\%), dan golongan Nitrofurans yaitu Nitrofurantoin (100\%). Bakteri gram positif $100 \%$ sensitif terhadap antibiotika golongan Glycopeptide (Vancomycin) dan golongan Nitrofurans (Nitrofurantoin). Bakteri Enterococcus faecalis sensitif terhadap antibiotika golongan Penicilin yaitu Ampicilin (100\%), Ampicilin sulbactam (100\%), Amoxycilin (100\%), Amoxycilin + clavulanic acid (100\%), Piperacilin (100\%), Piperacilin tazobactam (100\%), Benzyl peniciline (100\%), golongan Glycopeptide yaitu Vancomycin (100\%) dan golongan Nitrofurans yaitu Nitrofurantoin (100\%). Hasil tersebut sesuai dengan rekomendasi terapi HUGI (2015) yang menyarankan pemberian golongan penicilin (Amoxycilin + clavulanic acid, Benzyl peniciline) dan golongan Nitrofurans (Nitrofurantoin) sebagai salah satu pilihan antimikroba dalam kasus ISK asimtomatik (bakteriuria asimtomatik).

\section{ISK merupakan faktor risiko terjadinya persalinan preterm}

Pada penelitian ini didapatkan bahwa kehamilan dengan ISK (bakteriuria asimtomatik) merupakan faktor yang meningkatkan risiko terjadinya persalinan preterm. Hal tersebut sesuai dengan hasil penelitian yang dilakukan Mina dan $\mathrm{Ali}^{22}$ selama kurun waktu 2009 - 2011 di Mississippi yang menunjukkan bahwa ISK selama kehamilan meningkatkan risiko kira-kira 2 kali lipat untuk terjadinya persalinan preterm $(\mathrm{OR}=1,8$, IK 95\% = 1,3-2,4). Hasil penelitian lain yang dilakukan Sheiner dkk. ${ }^{18}$ dengan data medis selama periode 1988 - 2007, juga menyatakan bahwa pasien ISK dengan bakteriuria asimtomatik memiliki kemungkinan lebih tinggi mengalami persalinan preterm $(\mathrm{OR}=1.9 ; \mathrm{IK}$ $95 \%=1.7-2.0 ; \mathrm{p}<0.001)$.

Pada wanita kehamilan itu sendiri adalah keadaan yang unik dimana terjadi perubahan anatomi dan fisiologis saluran kemih.' Secara umum ISK terjadi pada 1-2\% kehamilan, dan bakteriuria asimtomatik terjadi pada $2-13 \%$ kehamilan. ${ }^{22}$ Bakteriuria asimtomatik pada wanita hamil normal kemudian akan dapat berkembang menjadi sistitis pada kehamilan adalah sebesar 33,3\% dan kemudian kemungkinan berkembang menjadi pielonefritis adalah sebesar $66 \%{ }^{23}$ Bakteriuria asimtomatik pada kehamilan yang mendapat pengobatan tepat akan dapat menurunkan angka kejadian pielonefritis sebesar $80 \%$ sampai $90 \% .^{13}$ Penapisan dan pengobatan bakteriuria yang tepat pada populasi ini direkomendasikan untuk mencegah pielonefritis dan masalah perinatal yang merugikan seperti persalinan preterm, prematuritas dan/ atau berat badan lahir rendah. ${ }^{10}$

Sebagian besar ISK terjadi karena adanya infeksi ascenderen. ${ }^{5}$ Bakteriuria dapat terjadi sebagai akibat adanya bakteri yang berasal dari reservoir fekal mendapatkan akses ke kandung kemih dengan cara menaiki saluran uretra. ${ }^{25}$ Dimana pada kasus ISK atas dan ISK bawah terjadi perpindahan organisme yang berasal dari usus atau mukosa vagina ke dalam saluran kemih. ${ }^{6}$ Mekanisme dasar masuknya bakteri ke dalam saluran kemih sepertinya sama pada wanita hamil maupun tidak hamil. Relaksasi otot polos yang dimediasi peran progesteron selama periode kehamilan diyakini berkontribusi pada pelebaran pelvis ginjal dan ureter sebagai serta menyebabkan gangguan peristaltik ureter, peningkatan retensi urin, dan meningkatnya kapasitas kandung kemih yang menciptakan lingkungan yang permisif dan menguntungkan untuk 
berpindahnya bakteri ke dalam saluran kemih. Dengan kata lain, terjadinya relaksasi otot polos yang selanjutnya diikuti dilatasi ureter disertai dengan adanya tekanan terhadap kandung kemih akibat dari membesarnya uterus yang terjadi pada masa kehamilan diketahui memfasilitasi berpindahnya bakteri secara ascenderen dari kandung kemih ke ginjal, yang meningkatkan risiko yang lebih besar terhadap bakteriuria untuk berkembang menjadi terjadinya pielonefritis. ${ }^{6}$ Dimana pada kondisi tersebut produk bakteri berupa endotoksin dapat terdeteksi di rongga amnion wanita yang mengalami persalinan preterm dan ketuban pecah sebelum waktunya. Endotoksin diketahui memiliki efek peradangan (proinflamasi) yang kuat di jaringan ibu dan janin dan dapat memicu dilepaskannya mediator-mediator inflamasi seperti IL-1 (Inteleukin-1), TNF (Tumor Necrosis Factor), PAF (Platelet Activating Factor) yang kemudian akan merangsang dihasilkannya prostaglandin yang kemudian akan memicu timbulnya kontraksi yang dapat mengawali kaskade persalinan. Berbagai organisme diketahui menghasilkan protease yang dapat mengurangi kekuatan membran khorionamnion. Selain itu juga menghasilkan fosfolipase A2 dalam kadar yang tinggi. Fosfolipase A2 adalah prekursor Prostaglandin yang berperan dalam inisiasi aktivitas rahim. ${ }^{26}$ Bakteri juga menghasilkan senyawa Matrix metalloproteinase (MMP) yang merupakan senyawa kolagenase yang akan melemahkan jaringan kolagen pada selaput membran khorioamnion sehingga selaput tersebut mudah robek. Degradasi kolagen juga terjadi di serviks uterus sehingga serviks menjadi matang (lunak). Resultante dari pematangan serviks, kontraksi miometrium, serta robeknya selaput ketuban akan mengawali kaskade yang mengawali terjadinya persalinan preterm.

Keterbatasan studi ini yaitu jumlah subjek penelitian yang terbatas. Selain itu penelitian ini baru dapat memeriksa dan membandingkan ISK sebagai salah satu bentuk infeksi, serta baru dapat mengekslusikan hipertensi dan anemia berat sebagai faktor yang dapat memicu terjadinya persalinan preterm. Sementara faktor penyebab persalinan preterm lainnya seperti stress, perdarahan desidua, overdistensi, serta kelainan medis lain belum dapat diekslusikan dalam penelitian ini dikarenakan keterbatasan waktu dan biaya. Sehingga ke depannya diharapkan dapat dilakukan penelitian selanjutnya terhadap variabel-variabel tersebut.

\section{SIMPULAN}

Berdasarkan hasil penelitian ini dapat disimpulkan bahwa kehamilan dengan ISK mempunyai risiko
13 kali lebih tinggi mengalami persalinan preterm bila dibandingkan dengan kehamilan tanpa ISK.

\section{KONFLIK KEPENTINGAN}

Penulis menyatakan tidak terdapat konflik kepentingan terkait publikasi dari penelitian ini.

\section{ETIKA DALAM PENELITIAN}

Penelitian ini telah mendapat persetujuan dari Komite Etik Fakultas Kedokteran Universitas Udayana/RSUP Sanglah Denpasar dengan nomer referensi kelayakan etik 160/UN.14.2.2.VII.14/ $\mathrm{LP} / 2019$.

\section{PENDANAAN}

Penelitian ini tidak mendapatkan bantuan dana dari pemerintah ataupun sektor swasta lainnya.

\section{DAFTAR PUSTAKA}

1. Masteryanto HM, Hardianto G, Joewono HT, Koendhori EB. Infeksi Saluran Kemih Sebagai Faktor Risiko Terjadinya Ancaman Persalinan Preterm. Majalah Obstetri \& Ginekologi. 2015;23(2):75-81.

2. WHO. WHO Recommendations on Interventions to Improve Preterm Birth Outcomes. World Health Organization Media Center; 2015.

3. ACOG. Preterm (Premature) Labor and Birth. Frequently Asked Questions Labor, Delivery and Postpartum Care; 2016.

4. Morken NH, Gunnes N, Magnus P,Jacobsson B. Risk of spontaneous preterm delivery in a low-risk population: the impactof maternal febrile episodes, urinary tract infection, pneumonia and ear-nose-throat infections. European Journal of Obstetrics \& Gynecology and Reproductive Biology. 2011;159:310-314.

5. Parveen K, Momen A, Begum AA, Begum M. Prevalence Of Urinary Tract Infection During Pregnancy. Journal Dhaka National Med. Coll. Hos. 2011;17(02):8-12.

6. Dielubanza EJ, Schaeffer AJ. Urinary tract infections in women. Med Clin North Am. 2011;95(1):27-41. DOI:10.1016/j.mcna.2010.08.023

7. Meiyanto J. The influence of maternal age and gestational age to urinary tract infection in Lempake Primary Health Care, East Kalimantan, Indonesia. Bali Medical Journal. 2019;8(3):762-766. DOI:10.15562/bmj.v8i3.1595

8. Gilstrap LC 3rd, Ramin SM. Urinary tract infections during pregnancy. Obstet Gynecol Clin North Am. 2001;28(3):581-591. doi:10.1016/s0889-8545(05)70219-9

9. Farkash E, Weintraub AY, Sergienko R, Wiznitzer A, Zlotnik A, Sheiner E. Acute Antepartum Pyelonephritis in Pregnancy: ACritical Analysis of Risk Factors and Outcomes. European Journal of Obstetrics \& Gynecology and Reproductive Biology. 2012. 162;24-27.

10. Hickling DR, Sun TT, Wu XR. Anatomy and Physiology of the Urinary Tract: Relation to Host Defense and Microbial Infection. Microbiol Spectr. 2015;3(4): 10.1128/ microbiolspec. UTI-0016-2012. doi:10.1128/microbiolspec. UTI-0016-2012

11. Smaill F. Asymptomatic Bacteriuria in Pregnancy. Best Practice \& Research Clinical Obstetrics and Gynaecology. 2007;21(3): 439-450

12. Kalita D, Deka S. Asymptomatic Bacteriuria in Pregnancy. The New Indian Journal of Obgyn. 2015;2(1):8-19. 
13. Whatmore WJ, Maccabe AF, Ross JA, McNair TJ. Urinary tract infection in a general surgical unit. Scott Med J. 1966;11(10):356-359.

14. Gebreslasie K. 2016. Preterm Birth and Associated Factors among Mothers Who Gave Birth in Gondar Town Health Institutions. Advance in Nursing. 2016; Article ID 4703138:1-5.

15. Bello M, Pius S, Ibrahim B. Characteristics and Predictors of Outcome of Care of Preterm Newborns in Resource Constraints Setting, Maiduguri Northeastern Nigeri. Journal of Clinical Neonatology. 2019;8(1):114-124.

16. Whalley P. Bacteriuria of pregnancy. Am J Obstet Gynecol. 1967;97(5):723-738. doi:10.1016/0002-9378(67)90458-9.

17. Zahroh F, Roebijoso J, Samsu N. Profil Kejadian Bakteriuria Asimtomatik serta Faktor-Faktor yang Terkait dengan Kejadian Bakteriuria Asimtomatik pada Ibu Hamil di Puskesmas Janti Kota Malang. Majalah Kesehatan FKUB. 2014;1(4):1-5.

18. Sheiner E, Efrat MD, Levy A. Asymptomatic Bacteriuria during pregnancy. The Journal of Maternal-Fetal and Neonatal Medicine. 2009;22(5):423-427.

19. Khan S, Rashmi, Singh P, Siddiqui Z, Ansari M. Pregnancyassociated Asymptomatic Bacteriuria and Drug resistance. Journal of Taibah University Medical Sciences. 2015;10(3):340-435.

20. Salvatore S, Salvatore S, Cattoni E, Siesto G, Serati M, Sorice P, Torella M. Urinary Tract Infection in Women. European Jurnal of Obstetric \& Gynecology and Reproductive Biology. 2011;156(2):131-136.

21. Mina Q, Ali D. Urinary Tract Infection (UTI) and Its Association With Preterm Labor: Findings From the Mississippi Pregnancy Risk Assessment Monitoring System (PRAMS), 2009-2011. Open Forum Infectious Diseases. 2015;2(1):1577.
22. Kodikara H, Seneviratne H, Kaluarachchi A, Corea E. Diagnostic Accuracy of Nitrite Dipstick Testing for the Detection of Bacteriuria of Pregnancy. Journal of Public Health. 2009;123:393-394.

23. Golan A, Wexler S, Amit A, Gordon D, David MP. Asymptomatic Bacteriuria in Normal and High Risk Pregnancy. European Journal of Obstetrics \& Gynecology and Reproductive Biology.1989;33:101-108.

24. Christensen B. Use of Antibiotics to Treat Bacteriuria of Pregnancy in The Nordic Countries. Which Antibiotics Are Appropriate to Treat Bacteriuria of Pregnancy? International Journal of Antimicrobial Agents. 2001;17: 283-285.

25. Macejko AM, Schaeffer AJ. Asymptomatic Bacteriuria and Symptomatic Urinary Tract Infection During Pregnancy. Journal of Urologic Clinic of North America. Urol Clin N Am. 2007;34:35-42.

26. CreasyRK, Resnik R, Iams JD, Lockwood CJ, Moore TR. Creasy \& Resnik's Maternal Fetal Medicine Principles and Practice 6th Edition. Saunders Elsevier. p 534-573.

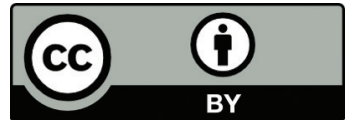

This work is licensed under a Creative Commons Attribution 